\title{
Silence of the World
}

\section{Scenic Experiment Script}

\author{
Ailton Krenak and Andreia Duarte \\ translated by Miro Spinelli
}

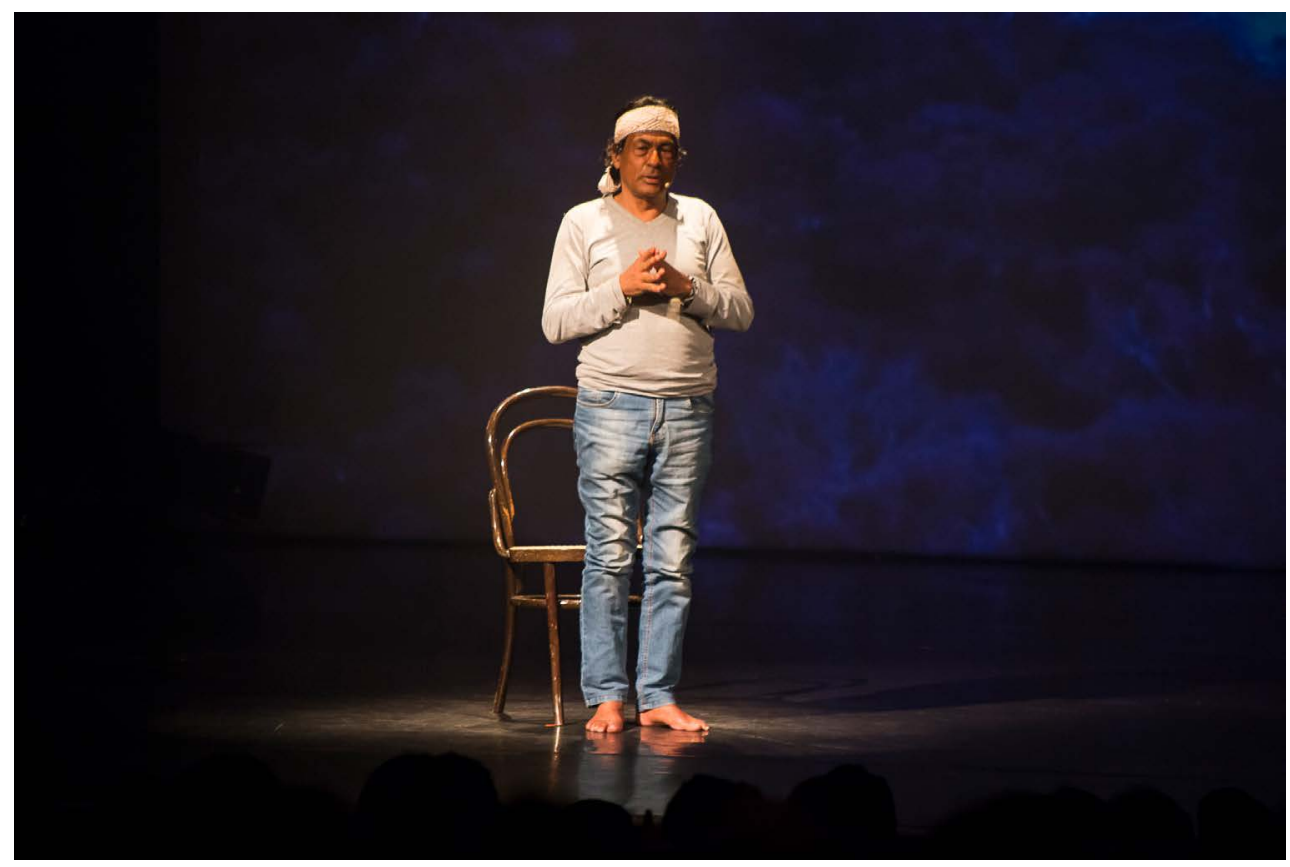

\section{Creative Team}

Ailton Krenak, Andreia Duarte-Devisers

Ailton Krenak, Andreia Duarte-Performers and Dramaturgs

Jezebel de Carli-Scenic Provocateur

Felipe Zancanaro-Sound Designer

Isabel Ramil-Video and Lighting Designer

Fernando Zugno - Creative Collaborator

Ernesto Neto-Creator of Sky

Outra Margem and Festival Porto Alegre em

Cena-Production
The performance of Silence of the World took place on 19 September 2019 during the 27th Festival Porto Alegre em Cena, International Festival of Performing Arts, in Porto Alegre, Brazil.

\section{Scene 1 The Forest}

(On the proscenium stage floor, the book The Falling Sky: Words of a Yanomami Shaman by Davi Kopenawa and Bruce Albert is open to page 256. There's a cyclorama at the back of the stage. In front of it, to the left of the audience, there's a chair. Above it all, a banging Sky. It is a work 
by the artist Ernesto Neto, placed above the stage. Light on the proscenium. ANDREIA DUARTE and AILTON KRENAK enter the scene and stop at the front.)

ANDREIA: Good evening. We are here to present a scenic experiment we produced during a week of immersion in the Festival Porto Alegre em Cena. We invited our dear friend Davi Kopenawa to be with us, but unfortunately, because his father-in-law passed away, he is in the midst of a long period of mourning and seclusion. We thank each of you for your presence, and may we be a part of this event together. Thank you.

(AILTON sits down on the chair. ANDREIA goes to the front of the stage and picks up the book. The lights go out. A vertical spotlight turns on above ANDREIA with the book in her hand.)

ANDREIA: (Reading) "My father-in-law did not travel as far into the white people's land as I have. Yet he is a shaman elder and his spirits already know all these things. When I describe one of my trips to him, he simply says: 'Your words are true! The white people's thought is full of ignorance. They constantly devastate the land they live on and transform the waters they drink into quagmires!' He was the one who truly made me wise by making me contemplate what the xapiri ${ }^{1}$ see. He often called me to say: 'Come close! I am going to expand your thought. You must not get old without becoming a true shaman. Otherwise you will never be able to see the forest's image with the xapiri's eyes!' Then I squatted down and drank the yãkoana, ${ }^{2}$ remaining in his company for a long time. Little by little, my eyes died under its power. Then once I became a ghost, my father-in-law's spirits carried me into the sky's chest. They flew there at high speed, taking my image and my breath of life with them. My skin remained on the ground in our house while my inner part crossed the heights."

(ANDREIA takes the book in her hands and leaves the stage. All the lights in the theatre go to blackout. A sound slowly enters and occupies the theatre space. Minimalist sounds evoke the forest's intimacy: the wind blowing through the leaves, animals walking, the river's current, birds communicating. For three minutes, the blackout space is filled by the sound of the forest. As the

1. The xapiri are spiritual beings of great complexity and diversity that live in the forest. They are fully connected with the Yanomami shamans who act to protect the world against their ills and the epidemics that affect humans (see Kopenawa and Albert 2013).

2. Yäkoana is a ritualistic substance that consists of a powder made from dried and pulverized tree barks. When inhaled, yäkoana initiates the user in the shamanic knowledge of his people (see Kopenawa and Albert 2013).

Figure 1. (previous page) Scene 2: The Time of the Myth. Silence of the World at the 27th Porto Alegre em Cena, International Festival of Performing Arts. (Courtesy of Fernando Zugno)

Andreia Duarte is an actress, director, and curator. For 20 years she has been working in the arts and as an ally and partner to the indigenous cause. She is a PhD candidate at São Paulo University (USP/ ECA), where she studies the crossings between theatre and indigenous peoples from an anticolonial perspective. She is Artistic Director of Outra Margem, a production company that creates artistic projects, such as festivals, performances, screenings, and books. andreia@outramargem.art; www. outramargem.art

Ailton Krenak is a prominent political and intellectual leader of the great awakening of the indigenous peoples in Brazil, which began in the late 1970s. His work has been fundamental to the struggle for indigenous rights and the creation of initiatives such as the Union of Indigenous Nations and the Alliance of Forest Peoples. He is Professor Honoris Causas at the Federal University of Juiz de Fora, and author of Ideias para adiar o fim do mundo (Ideas to Postpone the End of the World, 2019) and A vida não é útil (Life Is Not Useful, 2020). ailtonkrenak@gmail.com

Miro Spinelli is a Brazilian artist and a PhD student in the Department of Performance Studies at NYU.mirospinelli@nyu.edu 
sound grows quieter, an image of the Yanomami forest appears projected in the background. A spotlight is turned on above AILTON KRENAK sitting on the chair.)

\section{Scene 2}

\section{The Time of the Myth}

ANDREIA: (From backstage) Ailton, what is the time of the myth?

AILTON: We must be able to attempt a continued memory of who we are. In the case of indigenous peoples, continued memory has to visit a place they insist on calling myth because they want to empty it of historical meaning, so they call it myth. It turns out that all mythical narratives proclaim things that we have lived and recognize as history. The other day I was asking myself, what is this place that the myth informs you about? How does a thought rely on the myth narrative to develop and interact with the world? What occurred to me is that in the time of the myth we didn't feel the anguish of certainty. It sounds like a philosophical debate, doesn't it? The time of the myth happens when you haven't felt the anguish of certainty yet. You don't have to be certain; myth is a possibility, not a guarantee. It has no guarantee of duration or time; it is magical. It inaugurates, opens the door for you to go out in the world, interact and fulfill yourself in the world. And it is, always, a collective experience. It is not the subject; it is not self-made. Nothing is self-made in this story. People belong to collectives, their stories are in profound interaction with a constellation of people who, at their very base, have their cultural heritage - their grandparents, their ancestors. Regardless of what they worship, at the base of their mentality, of the way they present themselves to the world, lie the most ancient and ancestral memories.

So, these ancient memories help us to think about the possibility of interchangeable worlds that are able to alternate between different places and spaces; otherwise, borders will continue to be the most brutal and antihuman of marks. We need to leak out of these borders, like from a sieve, so we can move between worlds. That passing of the time when there was no anguish of certainty must refer to the instant just before the line divided peoples who have history from those considered to have myth. Olympus, for example-Mount Olympus - located close to Athens: it starts down at the Aegean Sea and goes up, spreading throughout that area. That mountain today is occupied by olive trees; it's a hill full of stones, no longer a place of the gods. It's no longer a place where deities cross through; it was reduced to a landscape to be transformed. The mountain ceases to be a sacred place, a place with creative and transforming potency that was once perceived as the Olympus, the place where power entities would move among humans, to the extent of establishing relationships with humans, having children, having consanguinity with humans.

When this is no longer a possibility, the vision of those people is impoverished. I am going to use an expression now that maybe is not the best one: they lose their vision, their cosmovision. They abandon a cosmovision and start pursuing an idea, an idea of pólis, of city, of society - an idea of a civilization that starts living with the anguish of needing to have certainty of something. Certainty that they will be able to control the place they are living in, the landscape. Certainty that, by means of knowledge, of science, of experimentation, they will be able to control the passing of time, the changing cycles of planting and harvesting, until they have reached this extreme we experience today, in which we no longer depend on the Earth's mood for our production, both our material production and our production of ideas.

(While AILTON talks, a community of crabs appears on the projection screen in the background.)

Somehow humans keep producing regardless of the mood of this immense Olympus that is the planet we live on. But, we share a big canoe-I insist on this image, in which the quality of the environment is not a concern for the majority of the crew, because the artifice that has been accessed-the science, 


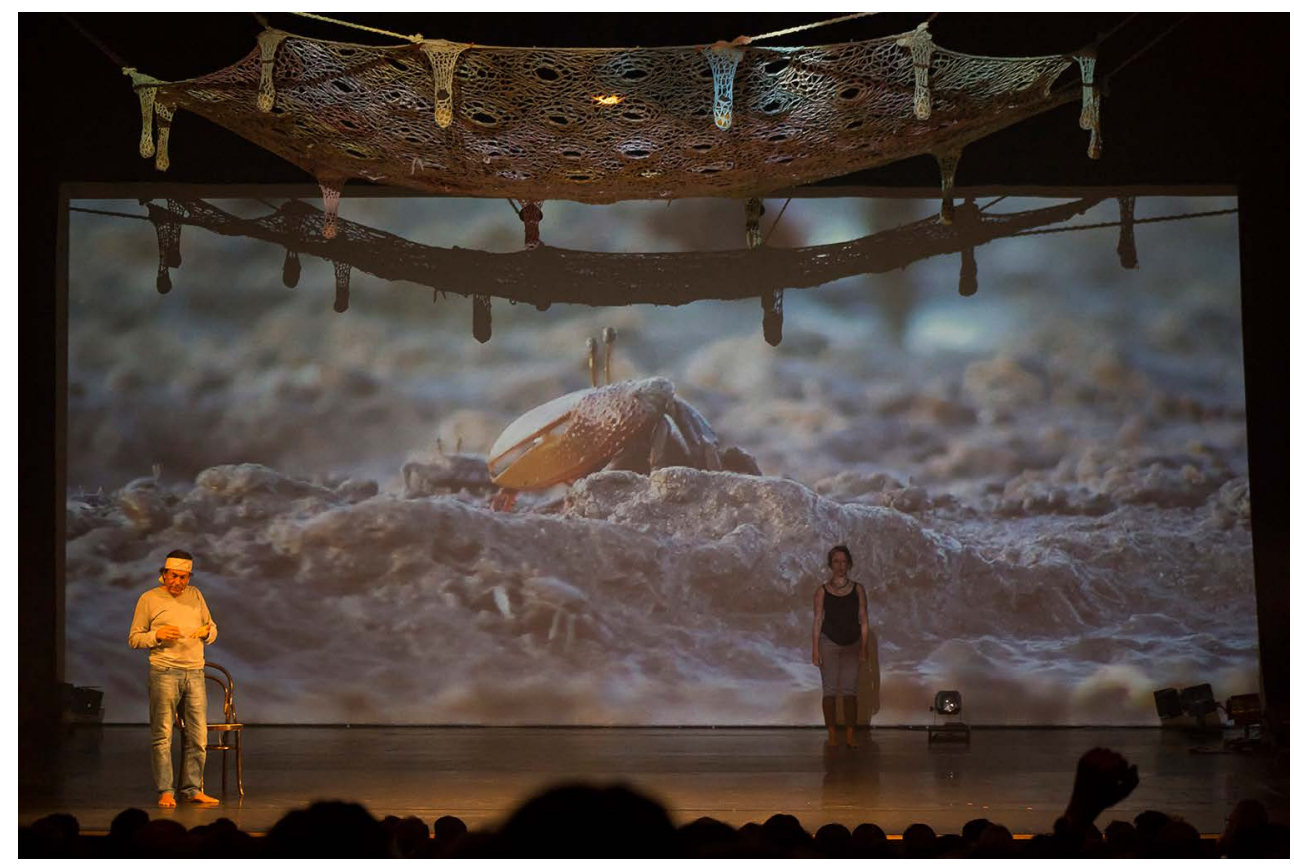

Figure 2. Scene 2: The Time of the Myth. Silence of the World at the 27th Porto Alegre em Cena, International Festival of Performing Arts. (Courtesy of Fernando Zugno)

the resources, the technology - what we call technology that has been accessed by humans - ruptures that sacred space relationship with the Earth that Olympus once had and other places continued to have later on. Their inhabitants broke with the idea that those places were sacred and started to also treat them as a resource- $\mathrm{a}$ resource available for the human to mold and manipulate. The growing understanding that myth is a knowledge category of the peoples who have no history, no pólis, no politics; who do not think about the complexity of the relations within the world we share, that understanding is a terrible segregationist legacy of a way of thinking that originated back with the Greeks.

I went to Athens with Davi Kopenawa Yanomami. The Brazilian Consulate in Athens sent someone to accompany us on a visit to the Acropolis, Hadrian's Arch, and the Temple of Zeus. We went to visit these places. When we arrived there, near the Aegean Sea, at a ruin with those broken columns, with fallen stones everywhere, remains of ancient temples lying on the ground and the beautiful sea in the background, it was a sunny beautiful day. We stopped, and our guide from the Brazilian Consulate stayed with us, contemplating the landscape. Then she asked Davi and me: "What did you think of this place? Did you enjoy the tour?" I entered a void, thinking about what I was going to answer. Davi was a little faster than me and said: "I liked coming here. Now I know where the miners who destroy my forest come from, digging through my forest as if it were dust. Their thoughts are here. They did it here and went on to do the same thing where I live. They turn the land over, they break everything."

This image, this translation made by the Yanomami shaman of our visit to that ruin in Greece, comes from a complete understanding of the mythical time in which the ancient Greeks lived, when Olympus was a place for the transit of sacred entities, as well as of the passage from that to a historical place where you can build monuments, temples, cities, and make wars. It's the transition between the time of myth - in which everything is possible, where it's possible for the worlds to interchange - to a flat world with a linear history. ${ }^{4}$ 
There's no ruler to measure time in the cosmic or cosmogonic narratives our ancestors experimented with and which some of us inherited from them, those of us with good hearing. If we were deaf we would also be using a ruler to measure time. ${ }^{5}$ Under these conditions during the mythical time, everything we believe is presented to us as "the world," according to what we experience, was yet to exist - as if it had happened before Time, when we weren't yet moved by this immense movement of ideas, resources, and means to measure time. We hadn't yet experienced the inner feeling of anguish about tomorrow. Tomorrow refers to our idea of time, prospective time, a kind of time that, like an arrow, is always directed at something we learned to think about as the future.

The time of the myth is a spiral, not an arrow. It's a place where our thinking can experience a state of suspension, as happens in meditation, for example. When someone stops thinking and does a meditation exercise, this person is able to visit that place prior to the anguish of certainty of tomorrow. Let's say we meet today and schedule a new meeting tomorrow. We are making an agreement about time with such arrogance and pretension that we are sure that tomorrow we will be here, or that we will be alive to fulfill this program. In fact, when we say "see you tomorrow," we are investing in this living uncertainty that we ourselves are living. We believe there is tomorrow. But we cannot abuse the idea of tomorrow as we have been doing for the past 200 years, when people have turned the expression "time is money" into a mantra. Maybe money is a measure of time, just like other things could be taken as measures of time. Who is passing by now, is it time?

(AILTON keeps on talking as ANDREIA enters at the back of the stage. She walks slowly and parallel to the projection screen, looking at the image of the community of crabs. The projected image covers her, too, and she becomes a part of the community.)
The time of the myth gives me the opportunity to summon other worldviews, which also imply other experiences of time. I evoked the image of people with a meditation practice so we could have at least one example of a possible exercise. Something that would allow one to experience being outside of the counting of time-money, outside of timecommitment, and to be able to experience one's inner time. This time liberates us from the incessant reaffirmation that we seek in the certainty of tomorrow. Tomorrow can be a present we receive for our perseverance and our patience with the day we are living today, which is the present of now, which is the meaning of the word "present." When we think about the past or the future, we are thinking about what doesn't exist anymore or what doesn't exist yet. Experiencing the living uncertainty is maybe the best way to dance with the experience of sharing our lives with a constellation of other beings that don't count time as we, the humans, do. We can summon a kind of humanity that also makes an appeal to other beings about life and existence. An adult tree can be 80 years old, or it can be 200 years old. Some sequoias are as old as 600,800 years, like perobas rosas and oaks, to mention only trees. But what about mountains? What's the age of mountains?

When counting time, we are much more mobilized by our anguish than by uncertainty. Maybe you too can experience inhabiting a time that is prior to the anguish we all share, in the kind of time that we experience in the world today. In the face of so many threats and so much violence, our very being is provoked to seek out certainties. But we can easily inhabit the experience of living uncertainty if we emphasize the meaning of life: life has no guarantee. Tomorrow is not for sale. I believe this is an invitation for us to think about living the present day, completely invested in the experience of each day with a renewed sense of the present instead of a sense of prospective time. It is the present that enables you to be an interior given to the world in the best possible way, right here and right now.

\footnotetext{
5. Krenak (2016). Deafness here is understood not as a physical disability but as a criticism of Western society for not listening to their ancestors and, for this reason, having to live confined to a linear time. - Trans.
} 


\section{Scene 3 \\ Woman Bird}

(The spotlights form a corridor of light on the stage. ANDREIA walks by.)

ANDREIA: The opportunity I had to live in an indigenous community promoted a displacement, a greater autonomy over time in my everyday life. I remember when I would go fishing in the late afternoon. On weekdays, like on a Tuesday. I always thought, while I was there inside of a canoe in the middle of a huge lake waiting for the time of the fish, that the people I knew, my friends and family, were all at that moment following their schedules, working eight hours a day in the city, with a time to wake up, to eat, to go out, a time for everything. It was a privilege to just stop when I didn't feel like doing anything. Although I was always inventing something to do.

There I felt I was being transported to another dimension. For example, every night someone would wake me up asking: "po ne wa up?" "Did you dream?" That happened because the Kamayura wake up in the middle of the night to ask each other what they are dreaming about. Then they ask again early in the morning. If you dream about something, if you dream about a jaguar, then you have to stay at home, you are not supposed to go anywhere else. There are also dreams that bring good things, and you are happy to know that the dream came to you.

So, it is not a distant thing, it is a part of life. It's not about giving priority to your finances and career development; it's about living a life that is constantly transported to other places, making connections, dancing, singing, swimming, listening to someone tell a story. All those free children. It has to do with that.

Maybe it is because of this everyday strength that the markings tattooed on my skin constitute a foundation that doesn't let me forget where I came from, or the notion that the paths I took make the choices I make more profound. I see this symbol, right? A language full of meanings comes, blurring all exclusivism in my being, scratching my body, which - while not racially, ethnically, or socially indigenous, or under the gaze of the other-has been inventing for itself the essence of remaining indigenous to the world, also a bird, also a woman.

\section{Scene 4 \\ Dancing and Singing to Suspend the Sky}

(AILTON and ANDREIA go to the center of the stage. They stand side by side, shoulder to shoulder. They inhale and exhale until they start to dance in a circle while singing.)

\section{AILTON and ANDREIA:}

Ehe ehe ehe, porã etê

Ehe ehe ehe, porã etê

Ehe ehe ehe, porã

Ehe ehe ehe, porã etê

Ehe ehe ehe, porã etê

Ehe ehe ehe, porã

Ehe ehe ehe, porã etê

Ehe ehe ehe, porã etê

Ehe ehe ehe, porã

(They inbale and exhale. Inbale and exhale.)

\section{Scene 5 Are There Too Many Whites?}

(AILTON and ANDREIA walk towards the proscenium. AILTON starts telling a story.)

AILTON: The second time I went to visit the Yanomami in the forest, one of them asked me:

ANDREIA: Ailton, is it true that there are too many whites?

AILTON: I thought to myself, how am I going to answer a question like this one? And I answered: "yes, they are too many." Then he asked me:

ANDREIA: But how many is too many?

AILTON: Then I answered something like this: "Like the sand, like the stars in the sky, this is how many the whites are." The other day my friend came around again.

ANDREIA: If they are too many, how do they manage to eat?

AILTON: What an amazing thought, if they are too many, what do they eat. Then I said: 
"They eat everything — sticks, leaves, rocks, dirt...they eat it all." My friend left and came back the next day with another question.

ANDREIA: What about their trash, where do they throw it away?

AILTON: "They throw it away in the world. In the whole world." Then he asked me:

ANDREIA and AILTON: Are they coming here?
Today we are the target of aggressions that, in essence, want to hurt our faith and our trust. Dignity still exists; it is still possible to build a society that knows how to respect the weakest ones, that knows how to respect those who have no money, but even so, there is an incessant defamation campaign going on. A people that has always lived without any wealth, that lives in houses covered with straw, and sleeps on mats on the ground, could never be by any means against Brazil's

\section{Scene 6 Calling}

(ANDREIA leaves the stage and AILTON sits on the floor. He looks at the screen. Pictures and videos of the "Global Climate Strike" are projected. They were taken in 2019 by teenagers and activists from all over the world when young Greta Thunberg started being considered a leader, calling the attention of world representatives to the planet's climate crisis. The images transition to a fragment of a video of AILTON giving a speech in defense of Indigenous Peoples' Rights at the Brazilian National Constitutional

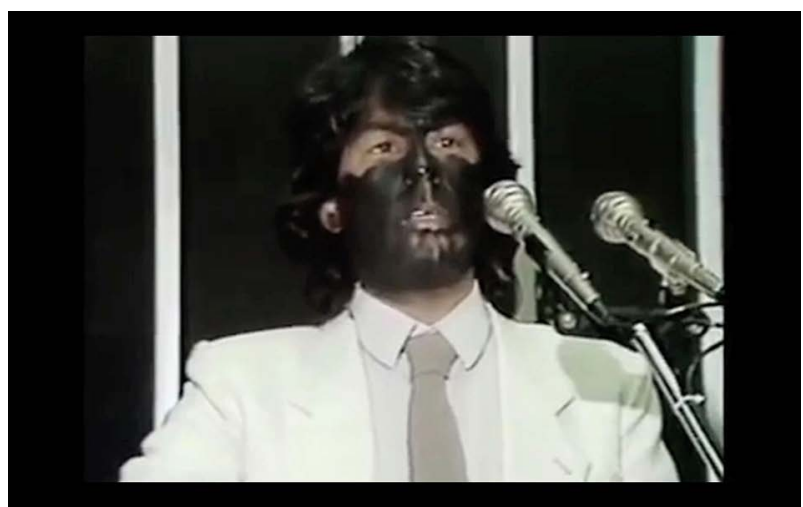

Figure 3. Scene 6: Calling. Krenak in the 1980s, his face painted black to personify mourning for indigenous peoples in front of parliament. Still frame from video recording used in Silence of the World. (Courtesy of Isabel Ramil)
Assembly in 1987, when be painted bis face black to express grief.)

AILTON: (Onscreen) Gentlemen, all of you know that indigenous people are far from having the power to influence the way you steer Brazil's destiny. On the contrary. We are maybe the most fragile parcel of the population in this conflict of interests that has shown to be extremely brutal, extremely disrespectful, and extremely unethical.

Indigenous people have a way of thinking, a way of living. The fundamental conditions of their existence and the manifestation of their traditions, of their lives, their culture, do not threaten and have never threatened the existence even of the animals that live in the surroundings of indigenous areas, let alone other human beings. I believe that not one of you gentlemen could point out actions or attitudes by the Brazilian indigenous people that have ever put anyone or anything at risk, may that be the life or the property of any person or group of people in this country. interest or put any kind of development at risk. Indigenous people have drenched every one of Brazil's eight million square kilometers with blood. And you gentlemen are the witnesses.

I thank the presidency, I thank the constituents, and I hope to not have hurt the feelings of those present in this plenary with my words. Thank you. (Long applause.)

\section{Scene 7 Is Meditation Still Possible?}

(ANDREIA enters the stage talking to AILTON.)

ANDREIA: But if individuation separates the world of the humans from the mountain, the rain, the sun, the air, the earth, creating a society that doesn't allow the existence of other forms of life, I ask myself: Is meditation still possible? Is there anyone that could make this meditation? 
(AILTON is still sitting on the floor: ANDREIA grabs the chair at the left of the stage and takes it to the right of the audience. The lights start dimming out and a spotlight turns on above her, now sitting on the chair. The sound of rain starts. She reaches out as if to feel the rain with her hands. ANDREIA gets up and starts walking. She stops and feels the rain on her body. Transversal spotlights slowly turn on, illuminating the stage. The sound of rain gets louder. ANDREIA lowers herself toward the floor. She stops with her legs stretched straight out and feels the rain. ANDREIA moves her body and meets AILTON stretched out on the floor. She lays down by his side.

They feel the rain.

AILTON gets up, sings and dances alone to the Thunder. The question appears on the background screen: IS MEDITATION STILL POSSIBLE? AILTON walks over and sits on the chair at the right. ANDREIA sits on the floor by bis side. AILTON starts speaking.)

AILTON: The Krenak village is located on the left bank of the Watu river, from where we can see, on the right bank, a rocky mountain range called Takrukrak. The tips of the mountains point to the sky, sharp stones like arrows pointing into space. My father, my grandfather, my cousins, they all look at the mountain as if it were our mother, as if it were our grandmother. They make ceremonies and sing to the mountain, they sing to the river. They look to the other side of the river and observe its mood - if the mountain is sad, happy or threatening, if there is a cloud over it, if it is going to rain or if the sun has risen in a clear sky, making the mountain all beautiful and shining. This is how the people in our house always resemble the mood of the mountain, the mood of our grandfather, Watu, and the mood of all the hills and rivers that surround the village. Also, when we camp in the forest, we wait for the wind to blow on the leaves to see if it teaches a new song, a new ceremonial chant. If someone hears it, they repeat it many times until they learn it. Then they sing it to their relatives, to see if it is recognized, if it is true. If it is true, it becomes part of our chant collection. ${ }^{6}$

This is why I talk about the place in which memory searches its foundation, informing the universal knowledge that is lived in the daily lives of our communities. It's great when the Krenak are able to retreat and take part in Taruandé, a ritual to make the sky move towards earth. At Taruandé, crawling young children, men, women, and elders sing and dance together, playing in a circle. They repeat sentences in their mother tongue that say "grandfather mountain, you and the river are my grandfathers"; "you are the fish for me to eat"; "you give medicine to my health"; "you clear my mind and my spirit"; and then "the wind, the fire, the sun, the moon." They repeat those sentences in their ancestral language, tapping their feet on the ground, playing the maraca ${ }^{7}{ }^{7}$ lighting fires, jumping in cold water, doing special therapies, and affirming their identities. ${ }^{8}$

All of this also concerns the ephemeral things that are taken by the wind or by the rain, and the houses, the objects, and ornaments. The accessories we use on each occasion are not only to ornament ourselves, they are also used to make us as similar as possible to the spectrum of our ancestors, who are dancing around us. We imitate them, we try to use signs so that they feel encouraged to be around us, because we look like them. We do it for them to think: "ah, my grandchildren like me, they look like me."

This is an indigenous way for them to think about origin, about their spiritual lineage, which allows them to live as they choose; for them to have a relationship with Brazilians, Portuguese, with people from Minas Gerais, from Espirito Santo, with Japanese, Germans, and with people from the whole world. The identity carried by people to this day, even after facing so much hostility, has not cut

6. Museu da Pessoa (2008).

7. The maracá is a rattle made of interwoven straw. It is usually used in rituals and by specific people, such as shamans or a music connoisseur. There are different types of maracas from different indigenous ethnicities. - Trans.

8. Coelho (2009). 
the connection we have with memory, with a river of ancestral memory that nurtures our existence. It is part of our familiar lives, part of our material lives; it is what sustains us in the sense of transcendence, with everything that exceeds our necessities of having land, food, of surviving with a sense of physical security related to these bonds. ${ }^{9}$

I belong to a generation that grew up speaking Portuguese, the regional language of our neighbors from Minas Gerais who live in the surrounding area of our river, the Doce River. This area has been colonized since the 1920s; for more than a hundred years it has been intensely colonized. Just like it happened here in Rio Grande do Sul, where the territories neighboring the Kaingang and Mbyá-Guaraní indigenous lands were occupied. It is such a close presence, such an intense harassment of regional culture, that it ends up suffocating the expression of the local languages. The culture of those small groups is eroded to the point that they integrate into the regional life without distinction. Traditional knowledge is so severely eroded that we soon become a community of equals. Equal in the sense of impoverishment; if only we were equals in the sense of sharing our best. This equality is a negative equality. We become more and more equal and more and more poor from the cultural point of view, from the diversity point of view, from the point of view of the knowledge about the ecosystems in which we live, the capacity to interact with the places where we live and need to live, with the places where we get water to drink, where we get food, where we get everything we need to make our shelters, to feel good, to feel comfortable. So, we slowly make the landscapes around the places where we live disappear, which is a mirror of another kind of disappearance, an internal one, that we expose ourselves to, and sometimes contribute to- -which is cultural erosion, right? We lose our own knowledge about our habitats and communities. Not only the human community, but all the communities that constitute the cultures and environments we experience. ${ }^{10}$

This is why I value the possibility of existence of families that look at themselves and are not ashamed to be who they are, nor to live in a house with a dirt floor; that are not ashamed to cook on a termite nest stove, on a rock; that are not ashamed to eat smoked meat and fish roasted on a rock, to eat potatoes and manioc taken from under the ashes; that are not ashamed to do that. I think this is a way of continuing to be Krenak. The Arabs and the Jews also play the drums, and the Japanese eat with chopsticks. It is a way for them to continue being Arabs, Jews, Japanese. Why can't we continue to be who we are everywhere? These people have to have the right to continue teaching their children the values that they have kept alive with them to this day. ${ }^{11}$

But I also want to bring up the magnificent experience that happens when collectives come together with their vision to sing and dance to suspend the sky. This means broadening our horizon in an existential sense, not only as a projection of something, or a desire. But a contribution to who we are, which is the matter that the time we live in wants to consume. If there is an urge to consume nature, there is also an urge to consume our subjectivities. So instead of putting them on the market, let's live our subjectivities freely, just as we are able to invent them. Since nature is being assaulted in such an indefensible way, let's at least keep our subjectivities, our visions and our poetics about life. We are definitely not the same, and it is wonderful to realize that each one of us here is different from the other, like constellations. The fact that we can share this space doesn't mean that we are the same, but it means that we are attracted to each other because of our differences. Let's have diversity, not a humanity labeled in a way that homogenizes us and takes away our joy

9. Krenak (1992).

10. Krenak (2015).

11. Coelho (2009). 
of being alive. That is why it is important for us to know about these communities that still exist around the world. ${ }^{12}$ When the sky is putting a lot of pressure on the planet, this is the parcel of humanity that sings and dances. If we don't do this, the pressure gets too great over our heads and we are left with no way out. I don't accept the checkmate, the end of the world or the end of history. When it gets too difficult, this is when I evoke this thought the most: singing, dancing, and suspending the sky. ${ }^{13}$

\section{Scene 8 \\ Singing and Dancing to Suspend the Sky}

(AILTON and ANDREIA go to the center of the stage and stand side by side. They inbale and exhale. Inhale and exhale. They start to dance in a circle, singing.)

Ehe ebe ebe, porã et $\hat{e}$

Ehe ebe ebe, porã et $\hat{e}$

Ehe ebe ebe, porã

Ehe ebe ebe, porã et $\hat{e}$

Ehe ebe ebe, porã et $\hat{e}$

Ehe ebe ebe, pora

Ehe ebe ebe, porã et $\hat{e}$

Ehe ebe ebe, porã et $\hat{e}$

Ehe ehe ebe, pora

Ehe ebe ebe, porã et $\hat{e}$

Ehe ebe ebe, porã et $\hat{e}$

Ehe ebe ebe, pora

Ehe ebe ebe, porã et $\hat{e}$

Ehe ebe ebe, porã et $\hat{e}$

Ehe ebe ebe, pora

Ehe ebe ebe, porã et $\hat{e}$

Ehe ebe ebe, porã et $\hat{e}$

Ehe ebe ebe, pora

\section{THE END}

\section{References}

CartaCapital. 2015. “'Se o bicho avançar, vamos encarar de pé,' diz Ailton Krenak.” 10 April. Accessed 5 November 2019. www.cartacapital. com.br/sociedade/201cse-o-bicho-avancar -vamos-encarar-de-pe201d-diz-ailton -krenak-1118/.

Coelho, Marco Antônio Tavares. 2009. "Genocídio e resgate dos 'Botocudo': Entrevista com Ailton Krenak.” Revistas Usp, Estudos Avançados 23, 65:193-204. São Paulo: Universidade de São Paulo. Accessed 15 September 2019. www. revistas.usp.br/eav/article/view/10447/12175.

Kopenawa, Davi, and Bruce Albert. 2013. The Falling Sky: Words of a Yanomami Shaman. Trans. Nicholas Elliott and Alison Dundy. Cambridge, MA: The Belknap Press of Harvard University Press.

Krenak, Ailton. 1992. "Antes, o mundo não existia." In Tempo e História, ed. Adauto Novaes. São Paulo: Companhia das Letras. Accessed 5 September 2019. docplayer.com.br/12411274

-Antes-o-mundo-nao-existia-ailton-krenak.html.

Krenak, Ailton. 2015. "Paisagens, territórios e pressão colonial" [Landscapes, territories and colonial pressure]. Espaço Ameríndio 9, 17:331-32. Porto Alegre: Universidade Federal do Rio Grande do Sul. Accessed 7 September 2019. https://seer.ufrgs.br/EspacoAmerindio /article/view/61133.

Krenak, Ailton. 2016. "As alianças afetivas. Entrevista com Ailton Krenak, por Pedro Cesarino." In Bienal de São Paulo: Incerteza Viva: Dias de Estudo, 178-79. São Paulo: Fundação Bienal de São Paulo. Accessed 7 January 2020. https://issuu.com/bienal/docs/32 bsp _reader_web.

Krenak, Ailton. 2019. Ideias para adiar o fim do mundo [Ideas to Postpone the End of the World]. São Paulo: Companhia das Letras.

Museu da Pessoa. 2008. "História: Rio de memórias." 14 March. Accessed 27 February 2021. acervo.museudapessoa.org/pt/conteudo /historia/em-contato-com-a-memoria-44619.

Souza e Silva, Jailson de. 2018. "Ailton Krenak-A Potência do Sujeito Coletivo, parte II.” Periferias (Rio de Janeiro), 18 May. Accessed 7 September 2019. revistaperiferias.org/materia /ailton-krenak-a-potencia-do-sujeito-coletivo -parte-ii/.

\footnotetext{
12. Krenak (2019).

13. Carta Capital (2015).
} 


\section{On the Creative Process}

\section{The Ephemerality of Silence of the World}

\author{
Andreia Duarte \\ translated by Miro Spinelli
}

In 2018 I invited the indigenous leaders Ailton Krenak and Davi Kopenawa to collaborate and coauthor the scenic experiment Silence of the World. The idea for the performance came from an expanded artistic research project on how to make a connection between theatre and the indigenous world. It's worth saying that Ailton Krenak is one of the most important intellectuals and emblematic leaders in Brazil; he expresses a profound reflection on the anthropocentric perspective as exclusivist, placing humans at the center of the world. His ideas cross several fields dealing with human existence, society, knowledge, and artistic practice. Equally important, Davi Kopenawa is considered one of the main Yanomami leaders and shamans; he was one of those responsible for the demarcation of the Yanomami Indigenous Land, and is known worldwide for his relentless fight for the survival of the Amazon forest. So, when I decided to invite two of the most important indigenous leaders in Brazil to enter the space of the performing arts, I did so based on principles established after expanded discussions about theatre and the indigenous world and through a deep relations of partnership and friendship with indigenous people that I have been building for over 20 years (see Duarte 2020).

Our meetings took place on the occasions when Krenak and Kopenawa came to São Paulo to attend events as guests of different institutions. I took the opportunity to listen to their speeches, reflect on and learn from their ideas, and make room for us to get to know each other better by creating opportunities for exchange. The truth is that it would be very difficult to achieve an ongoing dialogue if I were living somewhere other than São Paulo, which, being a large economic and cultural center of the Brazilian art market, frequently provides for indigenous representatives to come to the city. But the size of Brazil makes traveling difficult, as does the fact that each of these leaders lives on opposite sides of the Brazilian territory: Ailton Krenak lives in the Krenak Indigenous Land in the state of Minas Gerais in the Southeast Region; and Kopenawa lives in the Yanomami Indigenous Land, which occupies the states of Amazonas and Roraima in the North Region.

The experience of observing and listening to the lectures of these leaders heightened my perception of how they express their thoughts and understandings of their origin by bringing speech closer to other bodily expressions. In the middle of one speech, after talking about the whole colonial process that culminated in the death of the Rio Doce, ${ }^{14}$ Krenak stopped, took out a maracá from inside his bag, and started to sing and dance. When he finished, he looked

14. On 5 November 2015 the collapse of the Fundão mining tailings dam occurred in the district of Bento Rodrigues, 20 miles from the center of Mariana, a town in the state of Minas Gerais, Brazil. The dam was controlled by Samarco Mineração S.A., a joint venture of the world's largest mining companies, Brazilian Vale S.A. and Anglo-Australian BHP Billiton (see Krenak 2017). 
at the audience and said, "These things make me so upset, so shocked, that I have to stop and sing." That simple unexpected act put me in a state of suspension. It was as if Krenak had forced everyone there to stop and breathe, while also teaching us to resist engaging in violent verbal exchanges and instead to accept that there are other ways to help us communicate and encourage our well-being in the midst of so many difficulties.

Something similar happened right at the beginning of a lecture given by Kopenawa: he sat down on his chair, looked at his audience, and began to speak in Yanomami for about 15 minutes. It was so interesting to be in that situation. It created discomfort in the audience that was there to hear his speech but could not understand anything he was saying. This choice showed the integrity of Kopenawa as a leader as he communicated with gestures and speech coming from his own language. Simultaneously, it created a tension that made me think about the imposition of coloniality on the value of the official Portuguese language.

It reinforced my awareness that we are in a country that was built on the diverse indigenous peoples who to this day speak their own languages; many of these living and unique cultures still suffer from a continuing process of erasure in the formation of Brazilian society. Kopenawa recreated in that space and for the public the feeling that he and the native peoples suffer when they are forced to speak another language in order to build relationships that can contribute to their lives outside of their villages.

Krenak's and Kopenawa's aesthetic and political attitudes disrupted the conventions of the lecture, which, the way I see it, resulted in an expanded presence. As I accompanied them, I realized both leaders acted as they did to express their thoughts, and that those actions embodied an aesthetic that originated in their cultures, and at the same time made political statements related to their social contexts. Krenak sang about the painful death of the Rio Doce that happened as a consequence of unbridled capitalist development. When Kopenawa gave the speech in his native language, he attested to the live presence of Yanomami people in the face of so many threats to their survival.

During the same period when I was meeting with these leaders, listening to their speeches, and observing their activist practices, Krenak and I initiated the art festival TePI (Theatre and Indigenous Peoples; Outra Margem 2021). The inaugural event took place in 2018, and the second festival was programmed for 2020 but had to be canceled due to the Covid-19 global pandemic. TePI's goal is to place center stage artistic productions by indigenous artists who express their work through their bodies. The festival also seeks to be in dialogue with productions that, on principle, understand that humans are not separated from nature. Instead, we are all integrated with nature, and the planet is a site for the collective survival of all that exists: humans and nonhuman entities such as animals, plants, mountains, bacteria, etc. It is about deepening the understanding that we are only one species and that we all have the common responsibility for the survival of the Earth. The way we see it, it is important that this concept permeates all fields of knowledge and manifests everywhere, including in works of art.

We used to say fazermos juntos porque decidimos fazer - doing it together because we decided to-which, in the context of our creative process, expressed the need to join indigenous and nonindigenous artists in a common movement. This is how we came up with the idea for Silence of the World as a scenic experiment to be performed on stage for a nonindigenous audience, where Davi Kopenawa, Ailton Krenak, and I could propose actions that would exemplify, aesthetically and politically, the perception of a life connected with everything in the world and that is nature.

For me, there was something very coherent about doing this experiment. I lived with the Kamayura people who speak Kamayura language and inhabit the Xingu Indigenous Park, located in the Central-West Region of Brazil in the state of Mato Grosso, from 2001 to 2005; since then, I have sought to relate my various practices as an artist to my experience of indigenous existence intersecting with my path and deepening that experience by creating actions 
collaboratively. I am not interested in temporary research, which often runs the risk of appropriating aspects of specific cultures for nonindigenous artistic creations. Mine is part of a larger purpose over a longer time period; I seek to create artistic works that value human diversity and encounters between alterities - artworks that are part of my activism against all kinds of violence generated by the colonial process. As part of this effort, it was an honor to create a show next to these indigenous leaders, Ailton Krenak and Davi Kopenawa, two people who have transformed my being.

Another project objective was to increase the visibility of indigenous people in the market of national and international festivals, as well as in cultural institutions, where only recently there has been a greater presence of contemporary indigenous art. There is still scarce recognition of indigenous theatre production in Brazil, and indigenous people are only occasionally invited to take part in works by nonindigenous artists. So, Silence of the World also intended to call attention to the relevance of indigenous people's practices to the field of performing arts, such as devising a performance that sought horizontality in the creative process and the sharing of authorship.

Both Krenak and Kopenawa had already participated in other artistic projects - including films, music albums, festivals, radio programs, exhibitions - when they accepted my proposal to get together and create art actions. As they both have very full schedules, I proposed staging three experiments to be performed at different times, each one with a week of meetings followed by a presentation of the results. It was also important to take into consideration the economic aspects of producing a performance that involved two prominent indigenous leaders and complicated logistics. Even so, we believed in its realization.

During Krenak's visit to São Paulo, we went to Pinacoteca, the oldest art museum in the city, to visit Ernesto Neto, a visual artist whose exhibition Sopro was installed there (Artequeacontece 2019). The three of us walked together to the park next to the museum, sat on the exposed roots of a tree, and talked about the making of Silence of the World. At Krenak's invitation, Neto agreed to create an artwork to be installed over our heads onstage: his rendering of a sky that refers to the monumental book The Falling Sky: Words of a Yanomami Shaman by Davi Kopenawa and French anthropologist Bruce Albert. At this meeting, Krenak explained his thoughts about the work and later reinforced the same idea in writing:

The action would be to make the "white woman's body" disappear on the scene, with the entrance of the WORLD element, which dilutes the stabilized division between human and nonhuman, extinguishing the notion of gender and race as a given term in interpersonal relationships. A deconstruction exercise of the anthropocentric discourse that stabilizes the human body as the measure of things and defines gender and race, savage and civilization, Indian and white. (Krenak 2021)

The idea of moving the human body out of the center of the world was foundational to our creative process. We deepened our conversation about the silencing of the planet as the lifeforms that inhabit it die. If even one species can die off, this means that humanity as a species can also be silenced. But, as Krenak explained during the creative process, "humanity may end, but nature will always have the potential to create other forms of continuity." We decided to perform our scene as a way to invoke the presence of communities of nonhumans, provoking humanity to reconnect with the Earth as an organism and to get out of the mindset that presumptuously denies the plurality of life forms (Krenak 2020:82). We suggested building this path through the experience of our encounter, during the creative process, and, as it happens in indigenous education, through conversations, lived experience, repetition, and observation.

In 2019, we got approval for the first experiment to take place at the Festival Porto Alegre em Cena. We had already confirmed our participation, but at the last moment, unfortunately, Davi Kopenawa had to cancel because his father-in-law had just passed away and he had to 


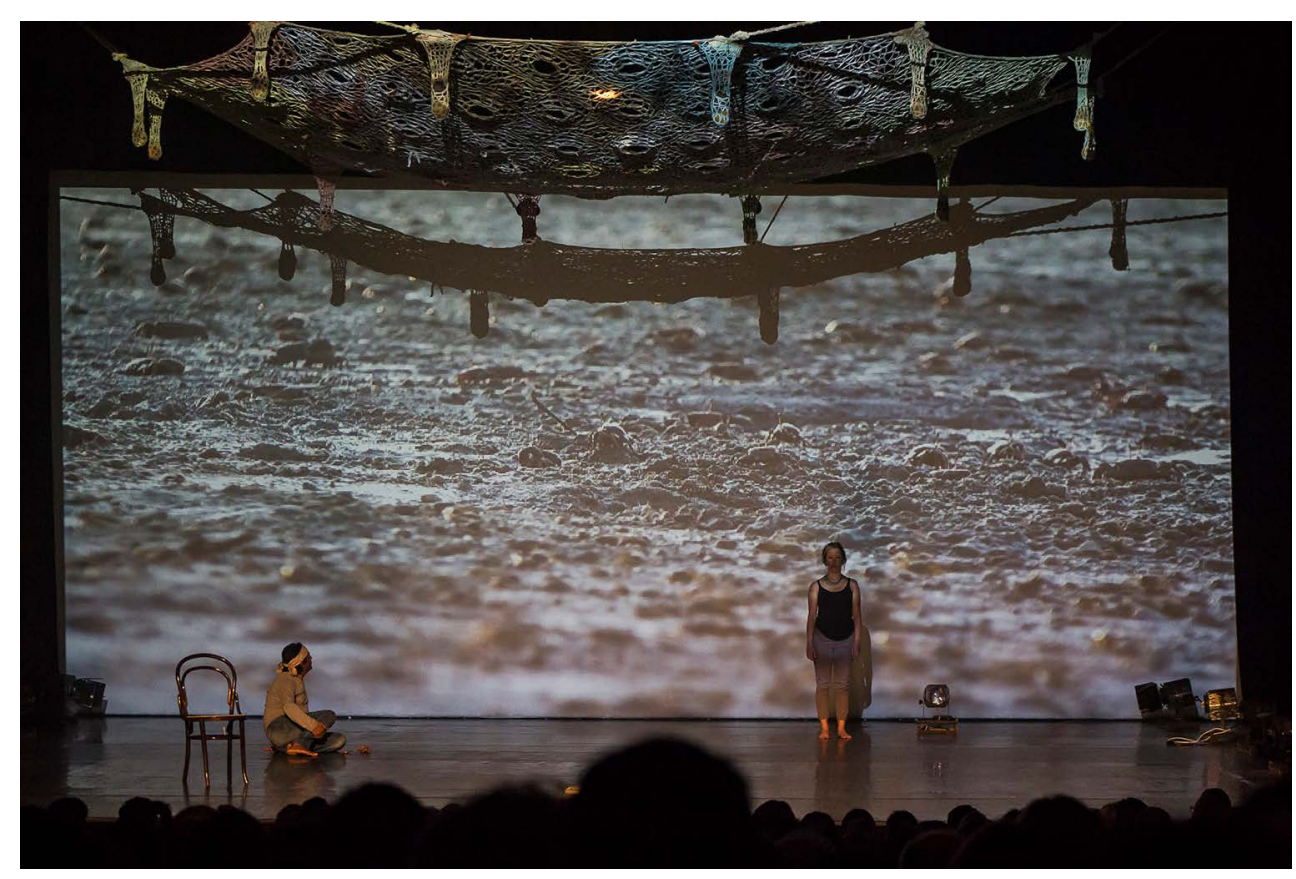

Figure 5. Scene 2: The Time of the Myth. Silence of the World at the 27th Porto Alegre em Cena, International Festival of Performing Arts. (Courtesy of Fernando Zugno)

undergo a long period of seclusion and attend to activities involved in the mourning of his people. Krenak and I decided to go to POA em Cena, but decided to invoke Kopenawa's presence by bringing to the scene fragments from our time with him. This is why we began the performance by reading to the audience a paragraph from the book The Falling Sky, in which Kopenawa shows the importance of his father-in-law in his formation as a shaman (Kopenawa and Albert 2013:256).

On the first day of our immersion, we spent more than eight hours talking and elucidating the ideas that would be communicated to the audience. We decided to work with the notion of the time of the myth, as developed by Krenak (in Souza e Silva 2018:4). This concept figures myth as an ancestral space, where all existences are aware that they are a part of the same community. It is a dimension that opens a gap where everything is possible, when life is created and transformed in each moment. This is how the relationship between humans and nonhumans begins, emerging in everyday life, in ritual; where we face dangers and form alliances. This happens, for example, when snakes start communicating with people, jaguars marry women, frogs pray inside villages that threaten all life within them, men turn into birds to court females, women fall in love with beautiful alligators that later turn into trees, rivers are created with their bends, mountains communicate with communities, storms get out of control, and the sky is supported by pillars, putting the planet at risk and in balance (see Kopenawa and Albert 2013; Krenak 2019; Kamayura and Kamayura 2013).

I think it is relevant to say that Krenak does not put forth this concept as something that is complete; it is part of a living memory that constitutes an environment visited all the time as a reference point for identity, place, and indigenous knowledge. This shows how original peoples live their ancestrality, putting their collective knowledge in motion in the present and thus laying the foundation for the future. The point of view of this living movement, here and now, 
reveals that indigenous people remain integrated with nature and do not make a distinction between body-human and body-world.

From this understanding, we started creating the scene in which Ailton Krenak, the Krenak leader, presented the time of the myth to the audience, while my body was subsumed by the image of a community of crabs projected onto the screen behind me. For us this evoked a sense that there was no separation between the white person, the woman, the indigenous person, the man, and the crab, but that everything is combined as part of the singular movement that is life. Further, we integrated my memories from when I lived with the Kamayura people to show the reality of the time of myth in that community. It is unimportant if the myth is real or fictional; what is important is to realize that it is a space of uncertainty in which there is no expectation of a secure future or a programmed life that desperately tries to postpone death. As one can read in the performance script, Krenak tells the audience that there is no guarantee of duration, but a magical dimension opens a window for us to cross over and go out into the world, interact, and fulfill ourselves.

Working alongside Krenak, Silence of the World made me think about the connection between worlds that we can build through artistic creation. It was interesting to note that, at the same time that we were talking about myth opening to possibility and to the invention of the world, we were in the process of imagining a new place. The scene emerged as a space of suspension, as we began to cross thoughts of the indigenous world with images, sounds, and memories in a construction that presented the audience with other ways of being, other senses. This is how we entered into the gap between the time of the myth and our presence, at a moment when we were willing to sing and dance to suspend the sky, without concerning ourselves with any thought of an end. We pushed this movement forward when we showed the young environment activist Greta Thunberg as a call to action for those who believe in transformation, as someone who inspired demonstrations against climate change and helped organize a worldwide movement. And when we showed Krenak in the 1980s, personifying the mourning of the indigenous peoples by painting his face black in front of several members of parliament, a gesture that is now part of the history of the formation of the Brazilian Constitution. ${ }^{15}$ And again when we paused...listening, seeing, touching; when we lay still under a diagonal light and listened to the rain falling; or stood still, just feeling.

The closing of the scenic experiment happened at the moment when we acknowledged that even after having gone through so much destruction of the world, and despite the arrogance of anthropocentrism, there are still people who mediate with the planet: those who are considered subhuman, people who cling to the Earth and, thus, are forgotten on the edges of the planet, on the banks of rivers, on the shores of oceans - caiçaras, indigenous, quilombolas, aborigines (Krenak 2020:82). This is how Krenak invoked Davi Kopenawa again, calling to the scene the thunder and the rain, as well as invoking the presence of the mountain that embraces the Rio Doce, the Takrukrak mountain, a sacred entity for his people:

I learned that the mountain has a name, Takrukrak, and a personality. In the morning, from the village yard, people look at her and know if the day is going to be good or if it is better to stay quiet. When she has an "I'm not up for a conversation today" face, people are attentive. When she dawns splendid, beautiful, with clear clouds over her head, all adorned, people say: "You can party, dance, fish, you can do whatever you want." (Krenak 2019:18)

Doing it together because we wanted to, we were driven by a creative process that brought with it an attempt to free ourselves from traditionalist ties about what art is, presenting a result

15. To watch part of this performance, go to https://www.youtube.com/watch?v=kWMHiwdbM_Q. 
made in a few days in the format of a lecture-performance. This was also possible due to the strength of the people involved in the festival: the programmer Fernando Zugno, who knew how to listen and believed in the project. The performance took place on the stage of the city's main theatre, the 100-year-old Theatro São Pedro, which had a capacity of 700 and sold out to an audience ranging from young people to elders, college students, professors from different fields, artists, journalists, representatives of the Kaikang and Guarani indigenous peoples, and a vast audience curious about what would happen on that traditional stage. After the performance, we received great affection from the audience and positive responses in different newspaper articles. In his column for the fornal do Comércio newspaper, theatre critic Antônio Hohlfeldt wrote:

But how to explain a show as deeply moving and creative as Silence of the World, conceived by Andreia Duarte and Ailton Krenak? That Thursday night was the highlight of the festival this year. The handmade net stretched over the heads of the performers; Ailton's simplicity and Andreia's dedication touched all of us who were there. In fact, it was as if we were all gathered around the original fire that night, listening to the noise of the past that the silence of the present wants to destroy. (Hohlfeldt 2019)

Finally, we were aware that we were provoking a fusion between real and fictional references, as well as between different scenic languages, such as lecture, video, and performance. We also knew that there was an ephemerality in everything that was happening, even in the very uncertainty of creating a performance in one week. Silence of the World was a unique event. Due to technical problems, the festival was unable to make a video recording. The only records that remain of the process are the ones in my notebook, memories, newspaper articles, and scenic materials. More recently, Krenak and I attempted to reconstruct the script. In any case, it has been very interesting to see how the work has been coming back by itself. Every now and then there someone asks questions, seeks information - wants to know a little more. I think that in a certain way Silence of the World created a life of its own, a life that marked our bodies and continues to animate us. Will it happen again, in another place, at another time?

\section{References}

Artequeacontece. 2019. “Ernesto Neto: Sopro.” 28 March. Accessed 27 February 2021. www.arteque acontece.com.br/ernesto-neto-sopro/.

Duarte, Andreia. 2020. "Indigenous Peoples and the Theater: A Possibility of Reinventing Life." ReVista: Harvard Review of Latin America 19, 3. Accessed 26 February 2021. https://revista.drclas.harvard.edu /indigenous-peoples-and-the-theater/.

Hohlfeldt, Antônio. 2019. "POA em cena: muitos acertos e alguns equívocos" [POA on the Scene: Many Hits and Some Mistakes]. Fornal do Comércio, Caderno de Artes Cênicas, 27-29 September. Accessed 12 July 2021. www.jornaldocomercio.com/_conteudo/colunas/teatro/2019/09/704352-poa-em-cena -muitos-acertos-e-alguns-equivocos.html.

Kamayura, Tacumã, and Kanutary Kamayura. 2013. Moroneta Kamayura: histórias Kamayura. Ed. Andreia Duarte. Belo Horizonte: Literaterras/FALE/UFMG.

Kopenawa, Davi, and Bruce Albert. 2013. The Falling Sky: Words of a Yanomami Shaman. Trans. Nicholas Elliott and Alison Dundy. Cambridge, MA: The Belknap Press of Harvard University Press.

Krenak, Ailton. 2017. "Se não fosse a persistência, já tínhamos acabado.” In Povos Indígenas no Brasil 2011-2016, ed. Beto Ricardo and Fany Ricardo, 156-65. São Paulo: Isa.

Krenak, Ailton. 2019. Ideias para adiar o fim do mundo [Ideas to Postpone the End of the World]. São Paulo: Companhia das Letras.

Krenak, Ailton. 2020. O amanhã não está à venda [Tomorrow Is Not for Sale]. São Paulo: Companhia das Letras.

Krenak, Ailton. 2021. Personal communication. Whatsapp, 15 February. 
Outra Margem. 2021. “TePI: Teatro e os povos indígenas.” Accessed 28 June 2021. https://en.outramargem .art/tepi-teatro-e-os-povos-ind\%C3\%ADgenas.

Souza e Silva, Jailson de. 2018. “Ailton Krenak-A Potência do Sujeito Coletivo, parte II.” Periferias (Rio de Janeiro), 18 May. Accessed 7 September 2019. http://revistaperiferias.org/materia/ailton-krenak-a -potencia-do-sujeito-coletivo-parte-ii/.

\section{TDReadings}

Brewer Ball, Katherine. 2020. "What Kind of Ancestor Do You Want to Be? First Nations Dialogues." TDR 64, 2 (T246):162-70. https://doi.org/10.1162/dram_a_00926.

Burelle, Julie. 2015. “Theatre in Contested Lands: Repatriating Indigenous Remains.” TDR 59, 1 (T225):97-118. https://doi.org/10.1162/DRAM_a_00431.

Ngũgĩ wa Thiong'o. 1997. "Enactments of Power: The Politics of Performance Space." TDR 41, 3 (T155):11-30. http://www.jstor.org/stable/1146606.

Teves, Stephanie Nohelani. 2018. "The Theorist and the Theorized: Indigenous Critiques of Performance Studies." TDR 62, 4 (T240):131-40. https://doi.org/10.1162/dram_a_00797. 